\title{
Stipetum novakii ass. nova - a new association of serpentine rocky grassland vegetation (Halacsyetalia sendtneri) in Serbia
}

\author{
Eva N. Kabaš $\check{1}^{*}$, Antun A. Alegro ${ }^{2}$, Nevena V. KuZmanović ${ }^{1}$, \\ KSenija M. JakovlJevićc ${ }^{1}$, SneŽana S. Vukojičić ${ }^{1}$, DMitar V. LaKuŠić ${ }^{1}$ \\ ${ }^{1}$ Institute of Botany and Botanical Garden, Faculty of Biology, University of Belgrade, \\ Takovska 43, 11000 Belgrade, Serbia \\ ${ }^{2}$ Department of Botany, Faculty of Science, University of Zagreb, Maruliceev trg 20/II, \\ 10000 Zagreb, Croatia.
}

\begin{abstract}
Phytosociological characteristics of grassland communities above serpentines (order Halacsyetalia sendtneri H. Ritter-Studnička 1970) in Serbia, are analyzed according to Braun-Blanquet methodology. In order to detect the basic floristic differentiation of analyzed communities ordinary correspondence analysis was applied. Cluster analysis was also performed to see the structure and separation of the communities based on the floristic composition. In order to determine diagnostic species, fidelity indices with presence/ absence data and the size of all groups standardized to equal size were calculated. The new association Stipetum novakii is described in open rocky serpentine grasslands in Brdjani Gorge.
\end{abstract}

Key words: Stipetum, serpentine, ordination, fidelity, Serbia

\section{Introduction}

Serpentine (ophiolithic, ultramafic) rocks represent a group of siliceous rocks which are characterized by calcium deficiency, high concentrations of aluminium, iron, magnesium, nickel, cobalt and chromium, and a few plant nutrients. In contrast to other acid siliceous rocks, the $\mathrm{pH}$ values of the serpentine substrate vary from basic to ultrabasic ( $\mathrm{pH} 5.5-8$ ). Serpentine flora and vegetation differ from those occurring on other types of siliceous substrates or limestone. Open serpentine habitats are characterized by pronounced thermophilous character and xeric conditions. The xerothermic character of serpentine plants is also enhanced by the specific chemical composition of the serpentine substrate (STEVANOvić et al. 2003). All of this results in a great number of specific adaptations (nanism, purpur-

* Corresponding author, e-mail: ekabas@bio.bg.ac.rs

Copyright ${ }^{\circledR} 2013$ by Acta Botanica Croatica, the Faculty of Science, University of Zagreb. All rights reserved. 
escence, glaucescence, stenophyllism, plagiotropism etc.) as well as the occurrence of numerous relic and endemic species.

The largest serpentine areas in Europe are in the Balkan peninsula (Epirus, Thessaly and Sterea Ellas in Greece, N, NC and SE Albania, C and E Bosnia, W, SW and C Serbia, E and C Rhodopes mountains in Bulgaria and gorge of River Pčinja and SE slopes of Mt Šar Planina in the NE part of Republic of Macedonia). In the territory of Serbia, the most frequent serpentine zones are in its C, W, NW and SW parts (JAKOVLJEVIĆ et al 2011). General overviews of the rich and interesting endemic serpentine flora in the Balkans are given by Tatić and Veljović (1990) and Stevanović et al. (2003).

In Serbia 19 associations were described in serpentine rocky grasslands (JovANOvić et al. 1986, LAKUŠIĆ and SABOVLJEVIĆ 2005) within the alliance Centaureo-Bromion fibrosi Blečić et al. 1960 (order Halacsyetalia sendtneri H. Ritter-Studnička 1970. Since the ultrabasic serpentine substrate appears between 500 to $1900 \mathrm{~m}$ a.s.1., their syntaxonomic diversity might be considerable, and this kind of vegetation requires a more objective revision of all syntaxa within the alliance Centaureo-Bromion fibrosi and order Halacsyetalia sendtneri.

The aim of this paper is to present the phytosociological analyses of the community dominated by Stipa novakii Martinovsky and compare it with the other communities of this type in Serbia, as well as to give an insight into the ecological characteristics in order to clarify its syntaxonomic position.

\section{Materials and methods}

\section{Study area}

The community dominated by Stipa novakii has been studied on serpentine rocky soils and small screes in different phases of genesis in Brđani Gorge in Serbia. Brđani Gorge is located high between Mt Vujan and Ilijak hill. It is $5 \mathrm{~km}$ long, $5 \mathrm{~km}$ away from the town of Gornji Milanovac, extending in a north to south direction, passing through the Ibarska highway. The gorge was cut by the Western Morava $3^{\text {rd }}$ rank tributary, the Despotovica. The sides of the gorge are slanted at an angle of $10-70^{\circ}$, at an altitude around $300 \mathrm{~m}$. Geologically, the gorge is mostly composed of the serpentine habsburgite-serpentinite. Rock erosion led to the formation of a pedological layer. These are rather shallow soils of low fertility and rock particles are abundantly and inherently present. The soil is eroded and has a mildly alkaline to neutral reaction (VIĆENTIJEVIĆ-MARKović 2004). The xerophilous oak forests of the alliance Quercion frainetto represent the potential of vegetation in this place (HoRvat et al. 1974). However, since the major parts of the forests are completely degraded, the dominant vegetation type in this place is steppe-like grassland vegetation. Climate type in this area is temperate-continental, but in its slighter subhumid variant (Fig. 1.). The annual mean temperature is $10.8{ }^{\circ} \mathrm{C}$ and the annual precipitation is $796 \mathrm{~mm}$. January is the coldest month with a temperature of $-3.8{ }^{\circ} \mathrm{C}$, while August is the warmest with atemperature of $26.5^{\circ} \mathrm{C}$. The wettest month is May with a precipitation of $89 \mathrm{~mm}$ and February is the driest, with $50 \mathrm{~mm}$ (HumANs et al. 2005). The vegetation period lasts eight months. It is important to say that the greatest amount of precipitation comes precisely during the vegetation season (from April to June), winter is the driest season, and winds are not frequent. 


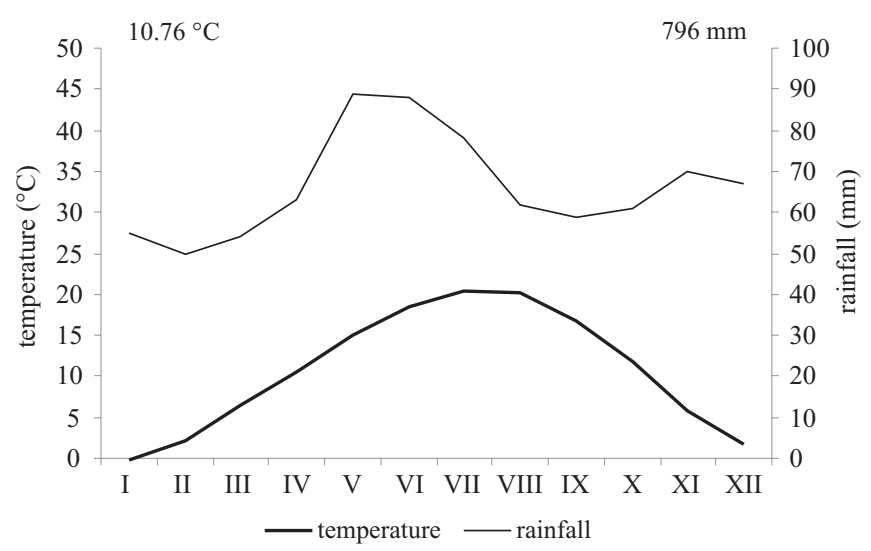

Fig. 1. The climate diagram for Brđjani Gorge in Serbia (from WALTER and LeITH 1964).

\section{Field sampling}

Sampling was done according to the methodology and protocols traditionally used in phytosociology. Relevés were made according to BRAUN-BLANQUET (1964). Plot size was usually 25 square meters, with the exception of three stands which were made on smaller relevé area $\left(6,20\right.$ and $\left.14 \mathrm{~m}^{2}\right)$ because of the terrain features. The stands were recorded on serpentine soil on altitudes between 320 and $360 \mathrm{~m}$ on south, east and south-east exposed slopes with an inclination of 10 to $40^{\circ}$. Cover of rocks within the stand area varied from 10-70\%. The sampling period was spring, 2011. Nomenclature of plant taxa, with a few exceptions, follows the Flora EuropaEa Database. All taxa with authors' names quoted in the paper are given in table 1 .

\section{Data analysis}

In order to detect specificity and resolve the syntaxonomy of the community dominated by Stipa novakii, we processed 185 relevés belonging to 18 associations traditionally included in the alliance Centaureo-Bromion fibrosi (Halacsyetalia sendtneri), distributed throughout the territory of Serbia (Table 1, Fig 2). The communities Eryngio-Brometum fibrosi Z. Pavlović, 1962 ex V. Randjelović 2004 and Halascya sendtneri-Potentilla mollis Z. Pavlović 1962, are described just on the basis of two relevés and hence not included in numerical analyses.

After transformation of Braun-Blanquet abundance-cover scale according to WESTHOFF and VAN DER MAAREL (1973), the relevés were subjected to correspondence analysis (CA) in order to detect the basic structure of the floristic composition. Relevés that showed a significant deviation from the main core of the relevés typical of the analyzed vegetation were excluded from further numerical analysis. Finally, the main core of relevés was classified using the UPGMA (unweighted pair-group average linkage) cluster method based on Chord distance as a heterogeneity measure. These analyses were performed using FLORA software (KARADŽıć et al. 1998).

Due to the fact that traditionally recognized characteristic and differential species, in most cases, have mainly regional validity, the same species can occur in different species 
Kabaš E. N., Alegro A. A., KuZmanović N. V., Jakovluević K. M., Vukojičić S. S., LaKušić D. V.

Tab. 1. Communities traditionally included in alliance Centaureo-Bromion fibrosi of order Halacsyetalia sendtneri, that are used to compare.

\begin{tabular}{|c|c|c|c|c|}
\hline No. & Associations & $\begin{array}{c}\text { UTM } \\
(10 \times 10 \mathrm{~km})\end{array}$ & Localities & Reference \\
\hline 1. & $\begin{array}{l}\text { Festuco duriusculae- } \\
\text { Euphorbietum glabriflorae } \\
\text { S. Jov. et R. Jov. }\end{array}$ & CP75 & $\begin{array}{l}\text { Tara, Zlatibor, } \\
\text { 980-1060 m a.s.1. }\end{array}$ & $\begin{array}{l}\text { JoVANOVIĆ et al. } \\
\text { (1992) }\end{array}$ \\
\hline 2. & $\begin{array}{l}\text { Festuco sulcatae-Potentilletum } \\
\text { zlatiborensis Z. Pavlović } 1951\end{array}$ & СТ94 & $\begin{array}{c}\text { Zlatibor, } \\
\text { 890-1020 m a.s.1. }\end{array}$ & PaVlović (1951) \\
\hline 3. & $\begin{array}{l}\text { Poo molinieri- Plantaginetum } \\
\text { holostei Z. Pavlović } 1951\end{array}$ & DP72 & $\begin{array}{l}\text { Studena Mt., } \\
\text { 910-1250 m a.s.1. }\end{array}$ & PAVlović (1951) \\
\hline 4. & $\begin{array}{l}\text { Artemisio-Teucrietum montani } \\
\text { Blaženčić, Vučković, R. } 1983\end{array}$ & DP91 & $\begin{array}{l}\text { Goč, Mitrovo Polje, } \\
710-810 \text { m a.s.l. }\end{array}$ & $\begin{array}{l}\text { BLAŽENČIĆ and } \\
\text { VUČKOVIĆ (1986) }\end{array}$ \\
\hline 5. & $\begin{array}{l}\text { Carici humilis-Festucetum } \\
\text { pancicianae R. Jovanović et } \\
\text { S. Jovanović } 1987\end{array}$ & DM79 & $\begin{array}{c}\text { Kopaonik, } \\
1650-1900 \text { m a.s.l. }\end{array}$ & $\begin{array}{l}\text { JovANOVIĆ-DunJIĆ } \\
\text { and JOVANOVIĆ } \\
(1987)\end{array}$ \\
\hline 6. & $\begin{array}{l}\text { Potentillo tommasinianae- } \\
\text { Festucetum pancicianae } \\
\text { D. Lakušić } 1989\end{array}$ & DM79 & $\begin{array}{l}\text { Kopaonik, Krmeljica, } \\
\text { 1050-1070 m a.s.l. }\end{array}$ & $\begin{array}{l}\text { LAKUŠIĆ and } \\
\text { RANĐELOVIĆ (1996) }\end{array}$ \\
\hline 7. & $\begin{array}{l}\text { Artemisio-Silenetum armeriae } \\
\text { D. Lakušić } 1989\end{array}$ & DM99 & $\begin{array}{l}\text { Kopaonik, Vlajkovci, } \\
\text { 700-750 m a.s.l. }\end{array}$ & $\begin{array}{l}\text { LAKUŠIĆ and } \\
\text { RANĐELOVIĆ (1996) }\end{array}$ \\
\hline 8. & $\begin{array}{l}\text { Sedo-Dianthetum serbici } \\
\text { Z. Pavlović } 1967\end{array}$ & DN77 & $\begin{array}{c}\text { Rogozna, } \\
\text { 500-850 m a.s.l. }\end{array}$ & PAVlOVIĆ (1967) \\
\hline 9. & $\begin{array}{l}\text { Potentillo-Fumanetum bonaparti } \\
\text { Rexhepi } 1979\end{array}$ & DN85 & $\begin{array}{l}\text { Ibar Valley - Kosovo, } \\
\text { 600-900 m a.s.l. }\end{array}$ & REXHEPI (1979) \\
\hline 10. & $\begin{array}{l}\text { Hyperico-Euphorbietum } \\
\text { glabriflorae Rexhepi } 1978\end{array}$ & EN05 & $\begin{array}{l}\text { Kopaonik, Barelj, } \\
1500 \mathrm{~m} \text { a.s.l. }\end{array}$ & $\begin{array}{l}\text { REXHEPI } \\
\text { (pers. comm.) }\end{array}$ \\
\hline 11. & $\begin{array}{l}\text { Onosmato-Scabiosetum } \\
\text { fumarioides Rexhepi } 1978\end{array}$ & DN60 & $\begin{array}{l}\text { Koznička Boka, } \\
\text { 800-960 m a.s.l. }\end{array}$ & REXHEPI (1985) \\
\hline 12. & $\begin{array}{l}\text { Polygalo-Genistetum } \\
\text { hassertianae Blečić et al. } 1969\end{array}$ & DN60 & $\begin{array}{l}\text { Koznička Boka, } \\
620-810 \text { m a.s.l. }\end{array}$ & $\begin{array}{l}\text { BLEČIĆ et al. } \\
\text { (1969) }\end{array}$ \\
\hline 13. & $\begin{array}{l}\text { Hyperico-Euphorbietum } \\
\text { glabriflorae Rexhepi } 1978\end{array}$ & DN80 & $\begin{array}{l}\text { Drenica, Nekoc, } \\
730-895 \text { m a.s.l. }\end{array}$ & $\begin{array}{l}\text { KRASNIQI and } \\
\text { MILLAKU (2007). }\end{array}$ \\
\hline 14. & $\begin{array}{l}\text { Sedo-Bornmüellerietum dieckii } \\
\text { Blečić et al. } 1969\end{array}$ & DN97 & $\begin{array}{l}\text { Šarplanina, Ostrovica, } \\
\text { 1280-1380 m a.s.1. }\end{array}$ & $\begin{array}{l}\text { BLEČIĆ et al. } \\
\text { (1969) }\end{array}$ \\
\hline 15. & $\begin{array}{l}\text { Bornmüellero dieckii- } \\
\text { Seslerietum latifoliae } \\
\text { S. Jov. et V. Stev. }\end{array}$ & DN97 & $\begin{array}{l}\text { Šarplanina, Ostrovica, } \\
1700 \text { m a.s.l. }\end{array}$ & $\begin{array}{l}\text { JoVANOVIĆ et al. } \\
\text { (1992) }\end{array}$ \\
\hline 16. & $\begin{array}{l}\text { Cynancho-Saponarietum } \\
\text { intermediae Blečić, Tatić et } \\
\text { Krasnići } 1969\end{array}$ & EM07 & $\begin{array}{l}\text { Šara Mt., Brezovica, } \\
820-1270 \text { m a.s.1. }\end{array}$ & $\begin{array}{l}\text { BLEČIĆ et al. } \\
(1969)\end{array}$ \\
\hline 17. & $\begin{array}{l}\text { Stipeto-Convolvuletum compacti } \\
\text { Millaku et al. } 2011\end{array}$ & EM16 & $\begin{array}{l}\text { Kosovo, Gurane, } \\
\text { 650-735 m a.s.l. }\end{array}$ & $\begin{array}{l}\text { MiLLAKU et al. } \\
(2011)\end{array}$ \\
\hline 18. & $\begin{array}{l}\text { Festuco-Plantaginetum serpentini } \\
\text { Randjelović et Ružić } 1982\end{array}$ & EM57 & $\begin{array}{l}\text { Preševo, Miratovac, } \\
\text { 600-960 m a.s.l. }\end{array}$ & $\begin{array}{l}\text { RANĐELOVIĆ } \\
\text { and RUŽIĆ (1983) }\end{array}$ \\
\hline
\end{tabular}




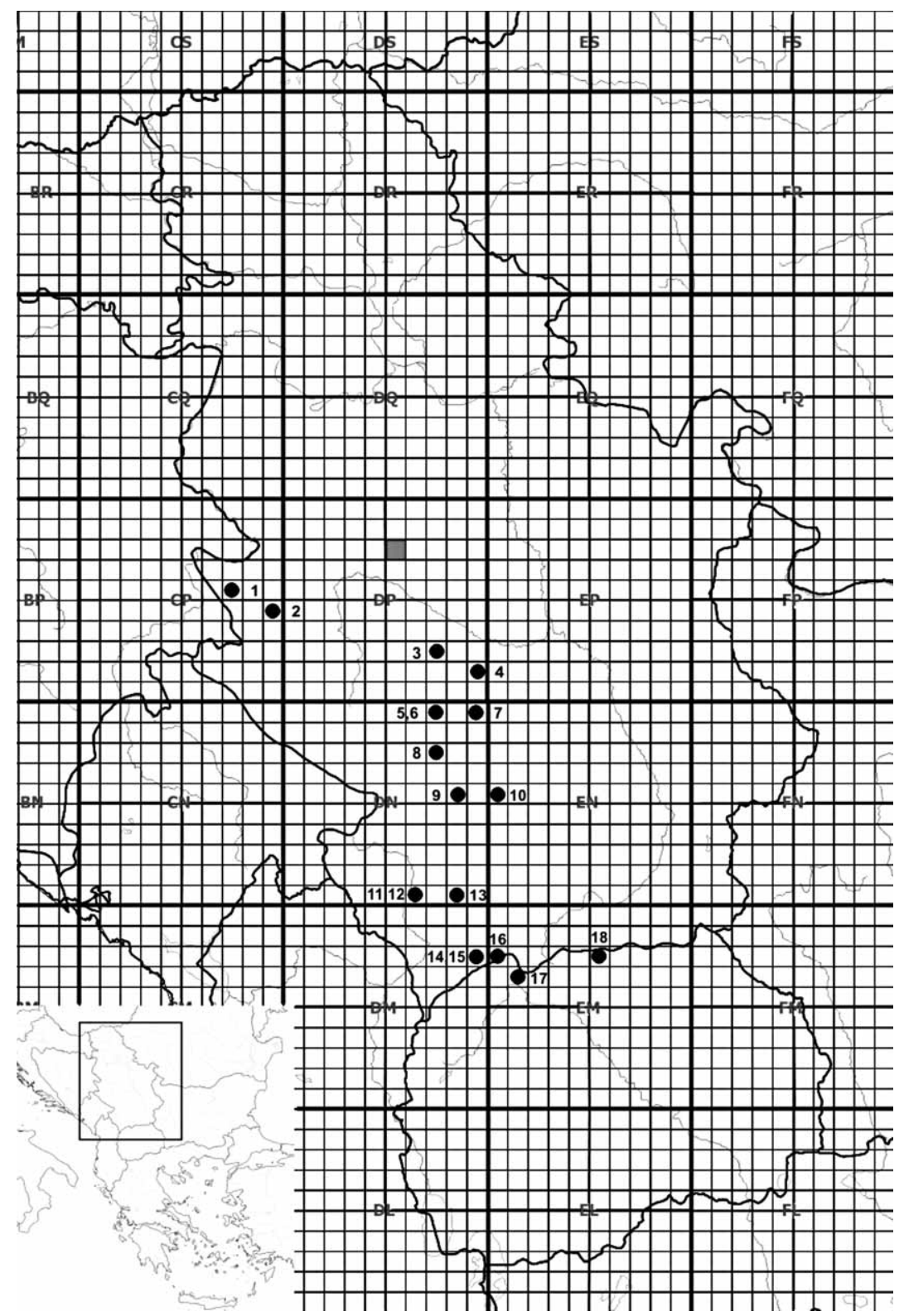

Fig. 2. The map of the localities of analyzed communities. The distribution is mapped using an underlying $10 \times 10$ UTM coordinate grid $100 \times 100 \mathrm{~km}$ (UTM Grid zone 34, the black dots with the corresponding ordinal numbers represents the localities of the communities listed in table 1. The black square represents the locality of the Stipa novakii community.

combinations in different regions (e.g. in other mountain ranges as a consequence of a different florogenesis). This is the case with all the mentioned lists of Balkan syntaxa in which characteristic and differential species are characterized with a high degree of 
subjectivity, rather intuitive than objective. Therefore, in this article, we used the concept of diagnostic and dominant species proposed by CHYTRÝ et al. (2002) and CHYTRÝ and TICHÝ (2003). Using the statistical measures of fidelity, we quantified concentrations of species occurrences in groups of classified sites in order to determine diagnostic species (CHYTRÝ et al. 2002). The size of the site groups in the data set is virtually equalized, while the relative frequencies of species occurrence within and outside of these groups are kept constant (TICHÝ and CHYTRÝ 2006). Then, fidelity is calculated using the $\Phi$-values of the association. With the use of this approach, species fidelity to a community types does not depend on the number of available field records. Since these values of fidelity measures are not the functions of statistical significance of fidelity, we performed the Monte Carlo test of significance of observed maximum indicator value for species with 4999 permutations. For the calculation of $\Phi$-values, PcOrd 6.0 software (MCCUNE and MEFFORD 2011) was used. In order to determine dominant species we calculated the coverage index (Ic) according to LAUSI et al. (1982). In the purpose of defining the geoelements we used the groupings made by Meusel et al. (1965, 1978), MEuSEL and JÄGER (1992), modified for the Serbian territory by STEVANOVIĆ (1992).

\section{Results}

\section{Ordination}

Correspondence analysis has shown that the relevés of ass. Festuco sulcatae-Potentilletum zlatiborensis are completely separated from the rest of the relevés along the negative part of the first principal axes (Fig.3), which correlates with the highest extent of variability (about 85\%). At the same time, this analysis completely separated the relevés with the domination of Stipa novakii from the rest of the communities along the positive part of the second axis. It can also be seen that the Kosovan site groups Festuco-Plantaginetum serpentini, Hyperico-Euphorbietum glabriflorae and Stipeto-Convolvuletum compacti are well separated along the negative part of the second axis. The rest of the relevés representing the Centaureo-Bromion fibrosi communities are concentrated in the centre of correspondence space.

\section{Classification}

The results of the cluster analysis, performed on the data set from which relevés of ass. Festuco sulcatae-Potentilletum zlatiborensis were excluded has shown that three main »stand groups « (clusters) could be differentiated. The cluster that separates at the highest heterogeneity level consists of two relevés from the ass. Poo molinieri-Plantaginetum holostei. These two stands are separated from the community they belong to, probably because they were recorded in open rocky grasslands, covering up to $25 \%$ and at higher altitudes of $1250 \mathrm{~m}$ a.s.l. From 91 species in total in these stands, only 10 and 12 species of the association are present. At the next level two main clusters can be seen, one of them representing the community dominated by Stipa novakii, and the other one representing the rest of the Centaureo-Bromion fibrosi communities. Within this last cluster, at different heterogeneity levels, 18 small subclusters can be distinguished. Each of them represents a more or less discrete community (Fig 4). 


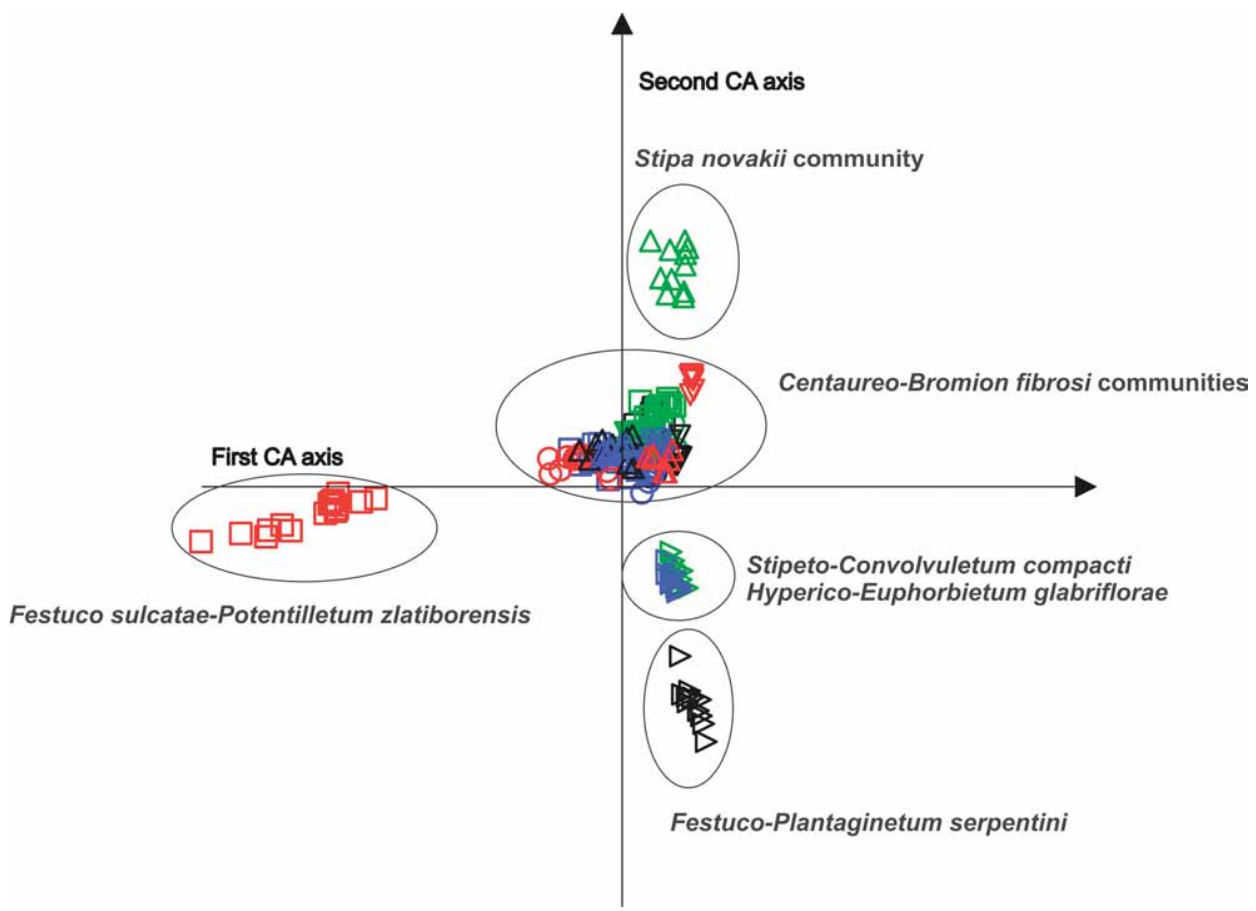

Fig. 3. Correspondence analysis (CA) of 19 analyzed communities of serpentine rocky ground vegetation traditionally included in alliance Centaureo-Bromion fibrosi of order Halacsyetalia sendtneri in Serbia.

\section{Dominant and diagnostic species}

Five taxa out of 476 were exclusively present in the Stipa novakii community from Brđani Gorge, whereas 445 taxa were exclusive for the rest of the analyzed communities (Centaureo-Bromion fibrosi) and absent from the relevés from Brđani Gorge. Only 26 taxa were present in both groups.

The most frequent and the most abundant species with large coverage indices in Stipa novakii community are: Stipa novakii Chamaecytisus hirsutus (L.) Link, Erysimum linariifolium Tausch, Silene bupleuroides L., Artemisia lobelii All., Galium purpureum L., Chrysopogon gryllus (L.) Trin., Polygala supina Schreber and Cheilanthes marantae (L.) Domin (Tab. 2).

Species with the highest $\Phi$-values, and a high degree of fidelity to this community are: Stipa novakii, Chamaecytisus hirsutus, Erysimum linariifolium, Polygala supina, Chrysopogon gryllus which again indicates that these species could be diagnostic for this community. A set of species characterized by relatively high Ic-values, but very low $\Phi$-values was the following: Leontodon crispus subsp. asper (Waldst. et Kit.) Rohlena, Halacsya sendtneri (Boiss.) Dörfler and Teucrium montanum L. (Tab. 2). High Ic-values and low $\Phi$-values indicate that they are common (with relatively large frequency, abundance and cover) in the investigated community, but without a diagnostic value for the Stipa novakii community. Their fidelity values are much greater in respect to some other communities of Centaureo-Bromion fibrosi, where they can even be a diagnostic species. 
Kabaš E. N., Alegro A. A., KuZmanović N. V., Jakovljević K. M., Vukojičić S. S., LakuŠić D. V.

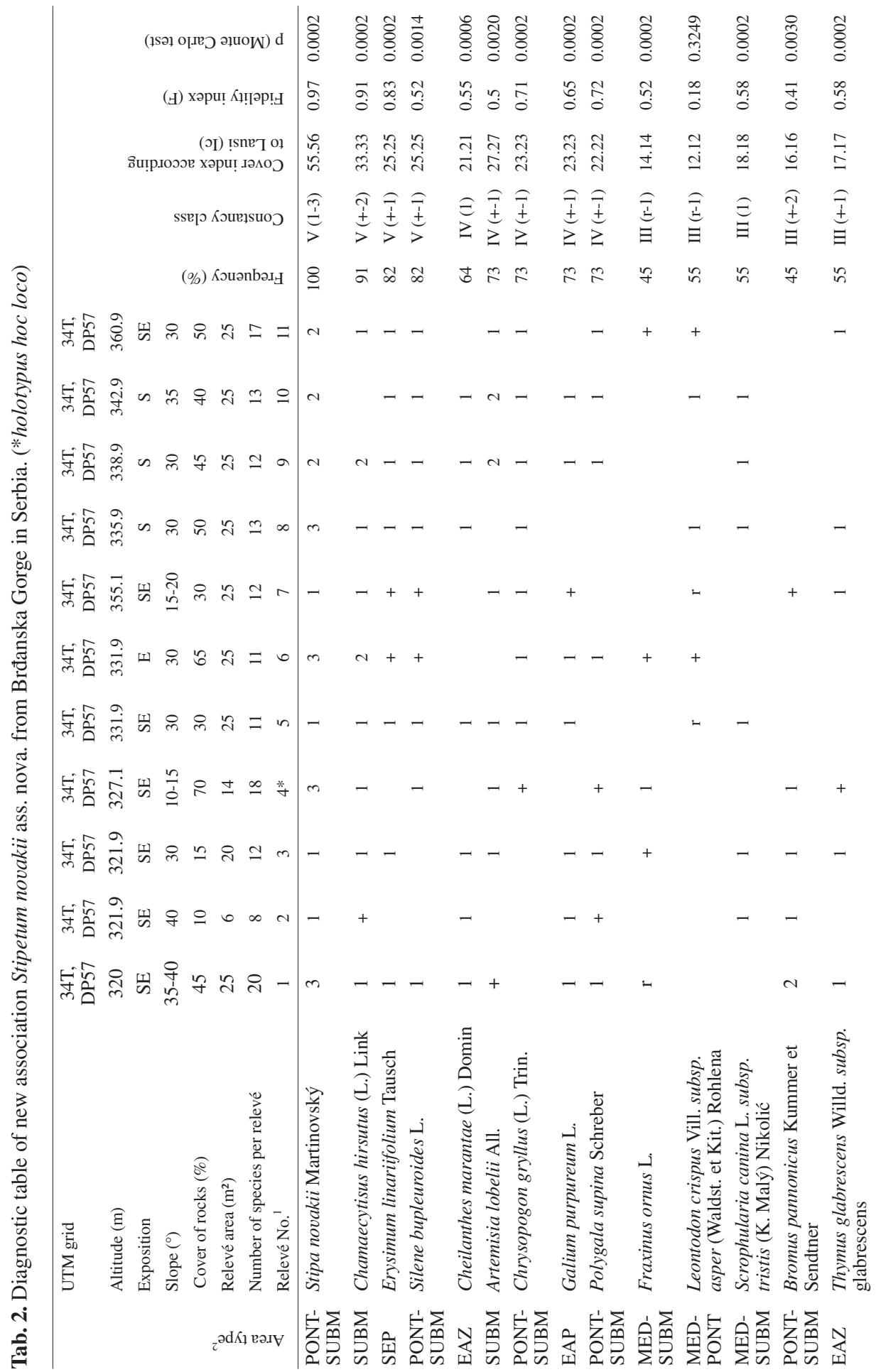




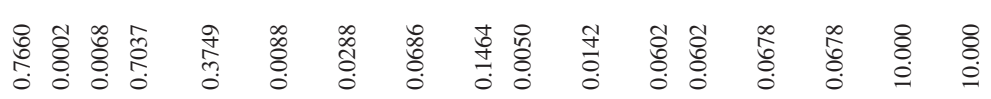

กำ

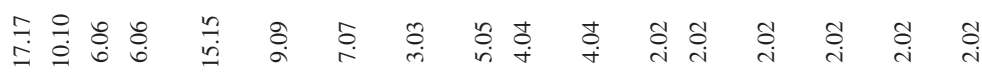

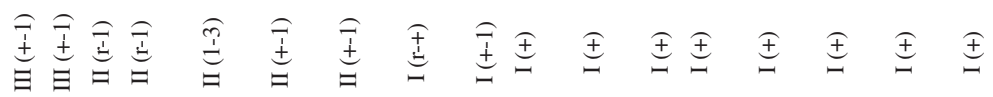

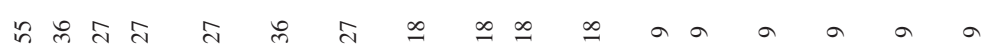

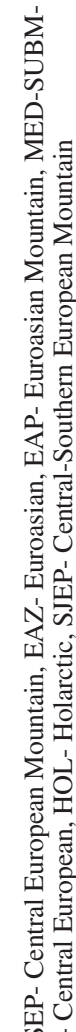

S

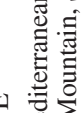

피율

$-+-\quad-\quad-\quad+\quad+$

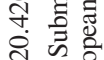

之̇

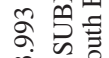

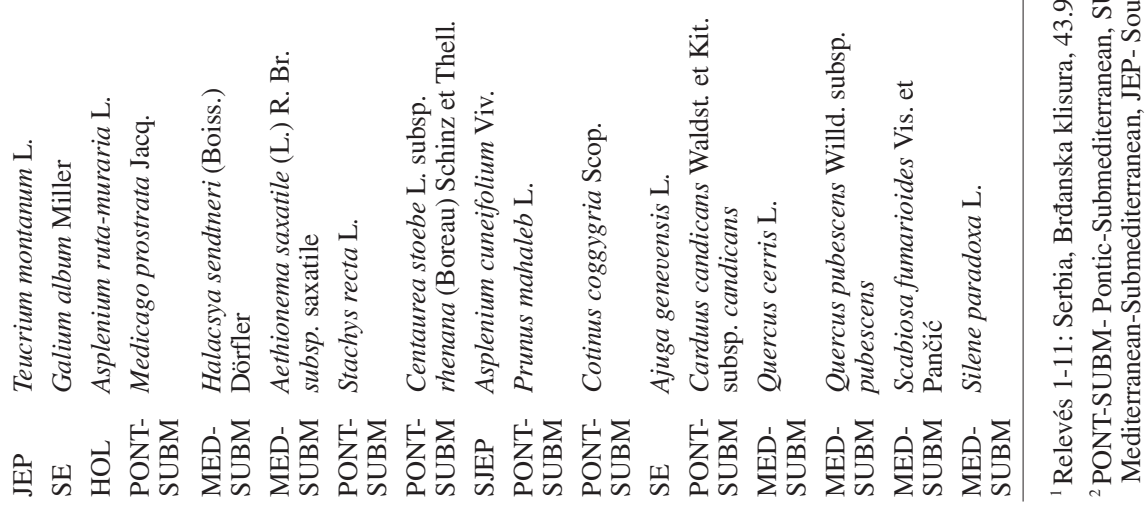


Kabaš E. N., Alegro A. A., KuZmanović N. V., Jakovluević K. M., Vukojičić S. S., LaKuŠić D. V.

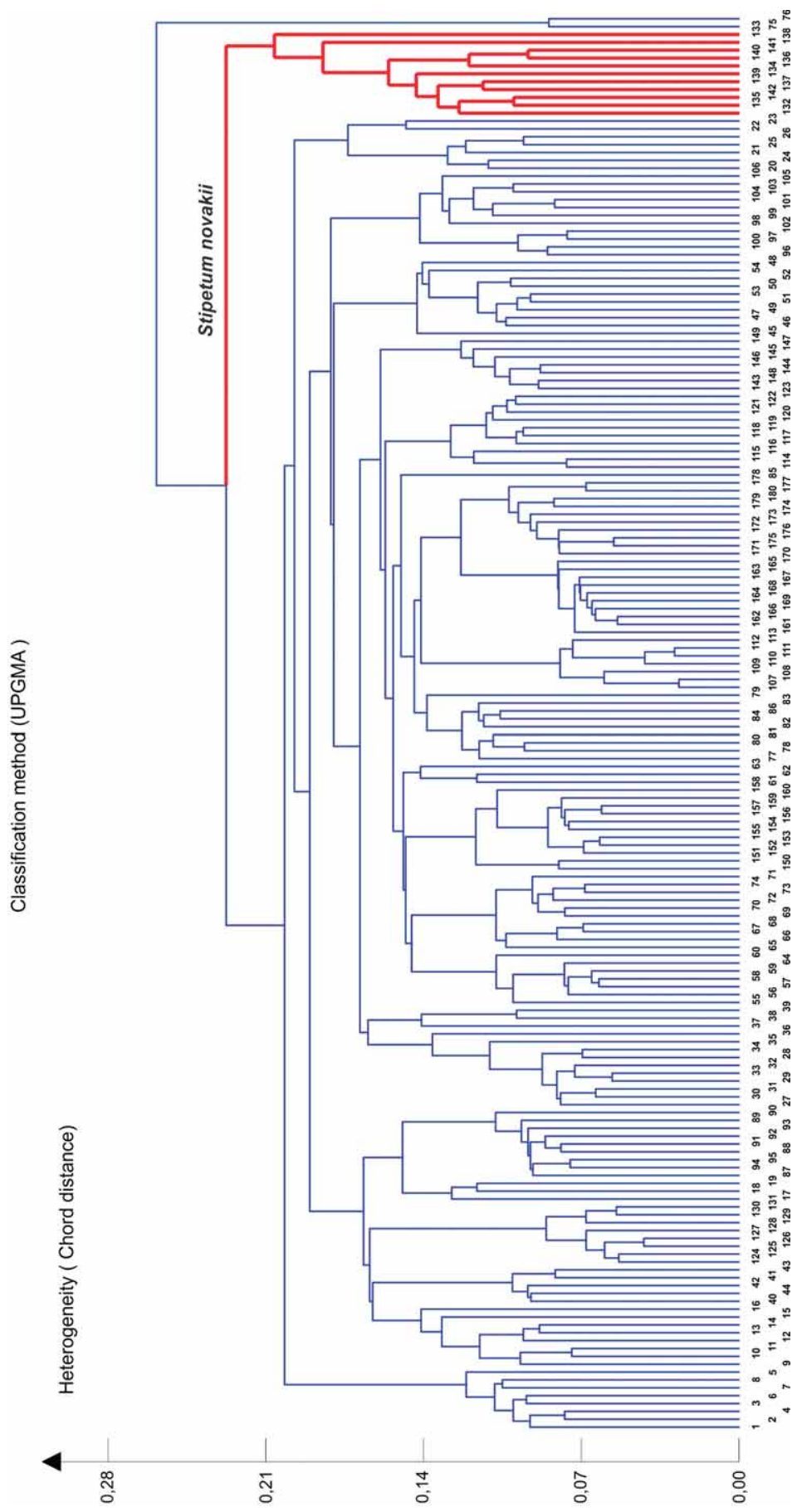

Fig. 4. Cluster analysis of the second data set of 18 analyzed communities of serpentine rocky ground vegetation traditionally included in the alliance Centaureo-Bromion fibrosi of the order Halacsyetalia sendtneri in Serbia. 


\section{Phytogeographic analysis}

Floristic composition of Stipa novakii community showed the dominance of species of Mediterranean-sub-Mediterranean and Pontic-sub-Mediterranean geoelements (11 taxa i.e. $35 \%$ in each chorological type). Taxa with centres of distribution primarily in the central European or mountain regions are present in much lower numbers (Tab. 2). Since the community is developed in serpentine open rocky grasslands, such a floristic composition was expected. These habitats are known to have extremely thermophilous character, conditioned by the serpentine geological substratum, and the deriving shallow and poor soils, developing on more or less steep slopes with southern expositions.

All the results presented suggest that the community dominated by Stipa novakii developed on open serpentine rocky soils in Brđani Gorge is well differentiated from other associations within the alliance Centaureo-Bromion fibrosi, and we propose a new association under the name Stipetum novakii ass. nova hoc loco.

\section{Syntaxonomical treatement}

\section{Ass. Stipetum novakii ass. nova hoc loco (Holotypus Tab. 2, rel. 4, Fig. 5)}

Dominant species: Stipa novakii (1-3) (Ic = 56), Chamaecytisus hirsutus (+-2) (Ic = $33)$, Erysimum linariifolium $(+-1)(\mathrm{Ic}=25)$, Silene bupleuroides $(+-1)(\mathrm{Ic}=25)$, Artemisia lobeli $(+-1)(\mathrm{Ic}=27)$, Galium purpureum $(+-1)(\mathrm{Ic}=23)$, Chrysopogon gryllus $(+-1)(\mathrm{Ic}=$ 23), Polygala supina $(+-1)(\mathrm{Ic}=22)$, Cheilanthes marantae $(1)(\mathrm{Ic}=21)$.

Diagnosis: Stipetum novakii is secondary rocky grassland developed on mostly SE and $\mathrm{S}$ (rarely E) exposed cliffs, with an inclination between $10^{\circ}$ and $40^{\circ}$. The dominant and characteristic species Stipa novakii with its dense tufts, forms poorly to richly developed stands up to $60 \mathrm{~cm}$ high, covering 10-70\% (average 40.9\%) of the relevé area (Tab. 2). The very poorly developed, thin pioneer soil layer with a large concentration of heavy metals

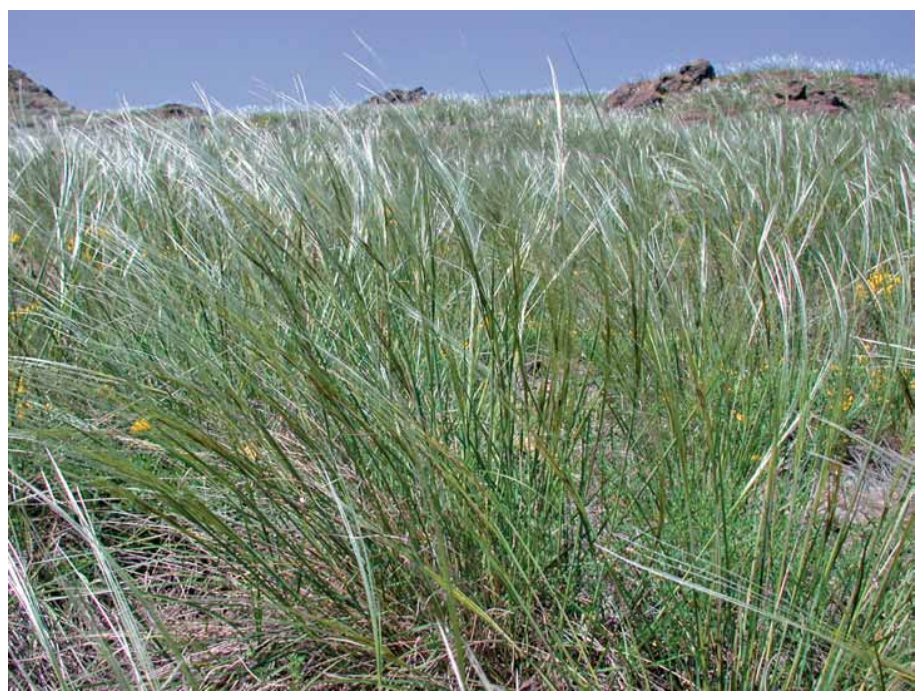

Fig. 5. Grassland of the association Stipetum novakii in Brđani Gorge serpentines (Photo: S. Vukojičić) 
results in there being relatively low plant diversity. In eleven relevés representing this community only 31 species were found. The average number of species per relevé was 13 . Diagnostic species of the association are: Stipa novakii, Chamaecytisus hirsutus, Erysimum linariifolium, Polygala supina, Chrysopogon gryllus, Galium purpureum. However, such a situation enables the development of a certain number of endemic serpentine species such as Stipa novakii, Halacsya sendtneri (Boiss.) Dörfler, Scrophularia canina L. subsp. tristis (K. Malý) Nikolić etc. Since the other characteristic species, as well as the differential ones, appear to be common accompanying species, we have chosen only Stipa novakii as a name giving species. The fact that it is endemic for very small serpentine area in western Serbia is also the criteria for Stipa novakii to be elected for the nominal species and also points up the endemic status of the community itself. The occurrence of some differential shrub and forest species, such as Chamaecytisus hirsutus, Prunus mahaleb L., Cotinus coggygria Scop., Quercus cerris L., Quercus pubescens Willd., distinctly characterizes this grassland community. The community basically represents a relatively short-term transitional syngenetic stage in the succession of vegetation, performing its role in binding and fixing the mobile substrate of mature screes on serpentine slope bedrock. The progressive succession will probably result in secondary grasslands of the Chrysopogonetum grylli type, after which shrubs and short trees will prevail in the physiognomy of the vegetation cover.

\section{Nomenclatural remark}

Holotypus: Tab. 2, relevé 4 - holotypus hoc loco

Syntaxonomical scheme

Festuco-Brometea Br.-Bl. et R. Tx. 1943

Halacsyetalia sendtneri H. Ritter-Studnička 1970

All. non defined

Stipetum novakii Kabaš et D. Lakušić ass. nova hoc loco

\section{Discussion}

In the analyzed serpentine rocky grasslands vegetation, only 5 out of 476 taxa were exclusively presented in stands dominated by Stipa novakii. All of the investigated communities had 26 taxa in common, with a certain number of Balkan serpentine endemics among them, such as: Scrophularia canina subsp. tristis, Silene bupleuroides, Scabiosa fumarioides Vis. et Pancic, Halacsya sendtneri and others, suggesting that they really do belong to the same higher syntaxa. Of the taxa, 454 were not recorded in the community from Brđani Gorge, and were present only in the rest of the Centaureo-Bromion fibrosi communities. The most frequent and the most abundant species present in the stands from Brđani Gorge is Stipa novakii. This is an endemic species for West Serbian serpentines. Its range descends southwards Kosovo, where it is gradually replaced with another endemic species, Stipa mayeri Martinovský. The endemic status of its dominant species implies the endemic status of the community Stipetum novakii itself.

Correspondence analysis has shown, firstly, that ass. Festuco sulcatae-Potentilletum zlatiborensis is completely separated from all other analyzed communities, representing well-supported syntaxa. In addition to its obvious detachment from other communities, we have noticed that the community was listed within Halacsyetalia sendtneri and Centau- 
reo-Bromion fibrosi by mistake. Due to ecological, physiognomic and structural characteristics such as closed plant cover with ground cover of 90-100\%, a typical grassland look, the fact that it is developed on plateaus (slope $=0-5^{\circ}$, extremely $15^{\circ}$ ) with the thicker soil layer with more humus, a higher floristic richness ( 86 registered species), in the original paper in which it was published, it was considered to be an intermediate syngenetic stage connecting the open serpentine vegetation of Poo molinieri-Plantaginetum holostei and the dry mountainous grasslands of Koelerietum montanae type (PAVLOVIĆ 1951). The authors consider that this association does not belong to the order Halacsyetalia sendtneri and should be listed within Festucetalia valesiacae Br.-Bl. et R. Tx. 1943 and Chrysopogoni-Danthonion alpinae Kojić 1957, but this exceeds the aim of this paper.

Furthermore, both numerical analyses have also shown that Stipetum novakii ass. nova significantly differs from the rest of the communities representing Centaureo-Bromion fibrosi. The fact that species Bromus erectus Hudson subsp. fibrosus (Hackel) Stojan. et Stefanov. is absent from the community from Brđani Gorge, as are most of the diagnostic species of alliance Centaureo-Bromion fibrosi, such as Centaurea kosaninii Hayek, Sedum serpentini Janchen, Alyssum montanum L. subsp. serbicum Novák, Thymus lykae Degen et Jáv., Stachys recta L. subsp. baldaccii (K. Malý) Hayek, Stachys scardica (Griseb.) Hayek, Euphorbia glabriflora Vis., Poa badensis Haenke ex Willd., Alyssum markgrafii O. E. Schulz, Plantago holosteum Scop. etc., indicates the high specificity and distinctiveness of this community and may lead us to think that its place is not at all within Centaureo-Bromion fibrosi. Regarding this, there is a high probability that Stipetum novakii ass.nova should belong to a new alliance, yet to be defined by further research. On the other hand, high $\Phi$-values in the species Scrophularia canina subsp. tristis, Cheilanthes marantae, Silene bupleuroides, Artemisia lobelii, Bromus pannonicus Kummer et Sendtner, Halacsya sendtneri, and negative $\Phi$-values within the species Festuca duriuscula L., Potentilla arenaria Borkh. var. tommasiniana (F. W. Schultz) Hegi, Koeleria splendens C. Presl, Danthonia provincialis DC., Festuca valesiaca Schleicher ex Gaudin subsp. sulcata (Hackel) Hegi, Festuca valesiaca subsp. pseudovina (Hackel ex Wiesb.) Hegi, indicate that the Stipetum novakii community should not be listed within xerophilous rocky grasslands of the order Festucetalia valesiacae, and its syntaxonomical position is, without any doubt, within the endemic order of the Central Balkans, Halacsyetalia sendtneri.

Since our numerical analysis showed that the heterogeneity level that separates Stipetum novakii ass. nova from the rest of the analyzed communities provides a sufficient basis for conferring on it the status of the association and also indicates that a new alliance should be introduced, further analyses are needed in order to get a more consistent syntaxonomic classification within the order Halacsyetalia sendtneri.

\section{Acknowledgements}

The authors are grateful to the Serbian Ministry of Science and Technological Development (Project No. 173030 Biodiversity of the plant life of Serbia and Balkan Peninsula Assessment, sustainable use and conservation (2011-2014)) for financial support. The authors also wish to thank the editor and reviewers for their valuable comments and suggestions, which significantly improved this manuscript. 
Kabaš E. N., Alegro A. A., KuZmanović N. V., Jakovluević K. M., Vukojičić S. S., LaKuŠić D. V.

\section{References}

BLAŽENČIĆ, Ž., VUČKOVIĆ, R., 1986: Meadow and pasture vegetation on southern slopes of the Goč Mountain in the Vicinity of Mitrovo Polje (In Serbian). Proceedings Symposium Man and Plant. Matica Srpska, Novi Sad, 441-448.

Blečić, V., TATIĆ, B., KRASNići, F., 1969: Three endemic communities on serpentine soil in Serbia (In Serbian). Acta Botanica Croatica 28, 43-48.

Braun-Blanquet, J., 1964: Pflanzensoziologie. Grundzüge der Vegetationskunde, 3. Springer, Wien - New York.

Chytrý, M., TichÝ, L., 2003: Diagnostic, constant and dominant species of vegetational classes and alliances of the Czech Republic: A statistical revision. Folia Facultatis Scientarum Naturalium Universitatis Masarykianae Brunensis. Biologia 108, 1-231.

Chytrý, M., TichÝ, L., Holt, J., Botta-Dukát, Z., 2002: Determination of diagnostic species with statistical fidelity measures. Journal of Vegetation Science 13, 79-90.

Flora Europaea Database: Royal Botanic Garden Edinburgh. Retreived November 23, 2012 from http://rbg-web2.rbge.org.uk/FE/fe.html

Hijmans, J., Cameron, E., PArra, L., Jones, G., Jarvis, A., 2005: Very high resolution interpolated climate surfaces for global land areas. International Journal of Climatology 25, 1965-1978.

Horvat, I., Glavač, V., Ellenberg, H., 1974: Vegetation Südosteuropas. Geobotanica Selecta 4. Gustav Fischer Verlag, Stuttgart.

Jakovljević, K., Lakušić, D., Vukojičić, S., Tomović, G., ŠinŽAR-Sekulić, J., STevaNOvić, V., 2011: Richness and diversity of pontic flora on serpentine of Serbia. Central European Journal of Biology 6, 260-274.

Jovanović, B., Lakušić, R., Rizovski, R., Trinajstić, I., ZuPančić, M. (eds.), 1986: Prodromus phytocenosum Yugoslaviae ad mappam vegetationis 1: 200 000. Scientific Council of the Vegetation Maps of Yugoslavia, Bribir - Ilok.

Jovanović-Dunjić, R., Jovanović, S., 1987: The succesion of vegetation on serpentine rocky grounds on eastern spurs of the Kopaonik Mountain. Archives of Biological Science 39, 93-102.

Jovanović, S., Stevanović, V., Jovanović-Dunjić, R., 1992: Contribution to the knowledge on the serpentine vegetation of Serbia. Glasnik Prirodnjačkog Muzeja u Beogradu, Ser. B 47, 43-51.

KARADŽIć, B., ŠAŠO-JovANOVIĆ, V., JovANOVIĆ, Z., PoPOVIĆ, R., 1998: FLORA - a database and software for floristic and vegetation analyzes. In: TsEKos, I., MoustaKAs, M. (eds.), Progress in botanical research, 69-72. Kluwer Academic Publishers, Dodrecht.

KrasniQI, E., Milaku, F., 2007: The association Hyperico-Euphorbietum glabriflorae Rexhepi 1978 in the serpentine terrains of Drenica Mountain. Hacquetia 6, 183-193.

LAKUŠIĆ, D., RANđELOVIĆ, V., 1986: Review of plant communities of Mt. Kopaonik (SW Serbia, Yugoslavia). Ecology 31, 1-16.

LAKuŠIĆ, D., SABovlJević, M., 2005: Phytocoenological classification of vegetation. In: LAKUŠIĆ, D. (ed.), Habitats in Serbia, results of the project »Harmonization of national nomenclature in the classification of habitats with the international standards « (In Serbian). Institute of Botany and Botanical Garden »Jevremovac«, Faculty of Biology, 
University of Belgrade, Ministry of Science and Environmental protection of the Republic of Serbia. Retrieved July 8, 2012 from http://habitat.bio.bg.ac.rs/nacionalne klasifikacije_stanista.htm

LAusi, D., Gerdol, R., PiCCOLI, F., 1982: Syntaxonomy of the Ostrya carpinifolia woods in the Southern Alps (N Italy) based on numerical methods. Studia Geobotanica 2, 41-58.

McCune, B., MefFord, M. J., 2011: PC-ORD for windows: multivariate analysis of ecological data, 6. MjM Software, Gleneden Beach.

Meusel, H., JÄGER, E., WeINERT, E., 1965: Vergleichende Chorologie der zentraleuropäischen Flora 1, Karten, Gustav Fischer, Jena.

Meusel, H., JÄGER, E., WeInERT, E., 1978: Vergleichende Chorologie der zentraleuropäischen Flora 2, Karten, Gustav Fischer, Jena.

Meusel, H., JÄGER, E., 1992: Vergleichende Chorologie der zentraleuropäischen Flora 3, Karten, Gustav Fischer, Jena-Stuttgart-New York.

Millaku, F., KRASNIQI, E., ReXHEPI, R., 2011: The association Stipeto-Convolvuletum compacti ass. nova in Kosovo. Hacquetia 10, 137-147.

PAVlović, Z., 1951: Vegetation of the mountain Zlatibor. Proceedings of the Institute of Ecology and Biogeography 11, 115-182.

PAVlović, Z., 1967: Sur une association végétale endémique des terrains serpentineux dans la vallée de la riviére Ibar (Serbie). Glasnik Botaničkog zavoda i Bašte Univerziteta u Beogradu, Nova serija 2,189-195.

RANĐElović, N., RuŽIć, M., 1983: Pastural vegetation on serpentine in south-eastern Serbia (association Festuco-Plantaginetum serpentini Ranđ. et Ružić 1982)((In Serbian). Bulletin du Museum d'Histoire Naturelle de Belgrade, Ser. B 38, 55-61.

ReXhePI, F., 1979: Endemic plant community Potentillo-Fumanetum bonapartei Rexhepi 1979, ass. nov. Acta Biologiae et Medicinae Experimentalis 4, 41-46.

REXHEPI, F., 1985: Endemic association Onosmo-Scabiosetum fumarioides Rexhepi 1978 on serpentines of Kosovo. Bulletin of the Ecological Society of Bosnia and Herzegovina 4 (B), 133-138.

STEVANOVIĆ, V., 1992: Floristic division of the territory of Serbia with an overview of higher chorions and appropriate floral elements. In: SARIć, M. R. (ed.), Flora of Serbia 1, 47-56. SANU, Beograd.

Stevanović, V., Tan, K., Iatrou, G., 2003: Distribution of the endemic Balkan flora on serpentine I. - obligate serpentine endemics. Plant Systematic and Evolution 242, 149-170.

TAtić, B., Veljović, V., 1990: Distribution of serpentinized massifs on the Balkan peninsula and their ecology. In: Roberts, B. A., Proctor, J. (eds.), The ecology of areas with serpentinized rocks, 199-215. Kluwer Academic Publishers, Dordrecht.

TichÝ, L., CHYTRÝ, M., 2006: Statistical determination of diagnostic species for site groups of unequal size. Journal of Vegetation Science 17, 809-818.

VićEntiJević-Marković, G., 2004: The serpentinophytae of the Brdjani gorge. Acta Agriculturae Serbica 9, 65-72.

WAlter, H., Leith, H., 1964: Klimadiagramm-Weltatlas 2. Gustav Fischer Verlag, Jena. 
Kabaš E. N., Alegro A. A., KuZmanović N. V., Jakovluević K. M., Vukojičić S. S., Lakušić D. V.

Westhoff, V., van Der MAAREl, E., 1973: The Braun-Blanquet approach. In: WhitTAKeR, R. H. (ed.), Ordination and classification of communities, Handbook of Vegetation Science 5, 619-726. W. Junk, Hague. 